\title{
Penerapan Lembar Kerja Siswa Berbasis Etnomatematika pada Materi Transformasi Geometri untuk Meningkatkan Hasil Belajar Siswa
}

Author:
Sinta Priciliya ${ }^{1}$
Affiliation:
${ }^{1}$ SMK Negeri 1 Pujer, East
Java, Indonesia
Corresponding author:
Sinta Priciliya,
sinpris0198@gmail.com
Dates:
Received: $13 / 6 / 2021$
Accepted: $3 / 7 / 2021$
Published: $9 / 7 / 2021$

\begin{abstract}
Abstrak. Pada pembelajaran matematika terdapat beberapa kesulitan yang dialami siswa. Salah satu cara untuk mengatasi kesulitan tersebut adalah dengan menerapkan strategi yang sesuai dengan karakteristik materi dan siswa. Pada materi transformasi geometri dapat menerapkan pendekatan Realistic Mathematics Education (RME) dan lembar kerja siswa (LKS) berbasis etnomatematika. Penelitian ini merupakan penelitian tindakan kelas yang bertujuan untuk meningkatkan hasil belajar siswa dengan menerapkan LKS berbasis etnomatematika pada materi transformasi geometri. Subjek penelitian adalah siswa dengan kemampuan matematika tinggi di SMK Negeri 1 Pujer. Metode pengumpulan data meliputi observasi dan tes. Hasil penelitian menunjukkan pada siklus pertama dengan menerapkan pembelajaran konvensional, siswa memperoleh skor rata-rata di bawah 60. Sdangkan pada siklus kedua dengan menerapkan pendekatan RME dan LKS berbasis etnomatematika, skor yang diperoleh rata-rata di atas 60. Berdasarkan hasil tersebut dapat disimpulkan bawha penerapan LKS berbasis etnomatematika pada materi transformasi geometri dapat meningkatkan hasil belajar siswa.
\end{abstract}

Kata kunci: LKS, etnomatematika, hasil belajar

\begin{abstract}
In learning mathematics, there are some difficulties experienced by students. One way to overcome these difficulties is to carry out a strategy that is in accordance with the characteristics of the material and students. In transformation geometry material, the Realistic Mathematics Education (RME) approach and student worksheets based ethnomathematics (LKS) can be applied. This research is a classroom action research which aims to improve student learning outcomes by LKS on geometry transformation material. The research subjects were students with high mathematical abilities at SMK Negeri 1 Pujer. Data collection methods include observation and tests. The results showed that in the first cycle by applying conventional learning, students obtained an average score below 60 . While in the second cycle by applying RME and LKS, the scores obtained were on average above 60 . Based on these results it can be concluded that the application of student worksheets based ethnomathematics on geometry transformation material can improve student learning outcomes.
\end{abstract}

Keywords: LKS, ethnomathematics, learning outcomes

\section{JoMEaL}

Copyright:

This work is licensed under a Creative Commons Attribution-ShareAlike 4.0 International License.

Read online:

https://jurnal.unej.ac.id/index.php/JOMEAL/index or scan barcode beside.

How to cite this article:

Priciliya, S. (2021). Penerapan Lembar Kerja Siswa Berbasis Etnomatematika pada Materi Transformasi Geometri untuk Meningkatkan Hasil Belajar Siswa. Journal of Mathematics Education and Learning, 1(2), 159-165. Retrieved from https://jurnal.unej.ac.id/index.php/JOMEAL/article/view/24358 


\section{Pendahuluan}

Pada pembelajaran matematika di sekolah, tidak sedikit siswa yang mengalami kesulitan untuk memahami materi yang dijelaskan oleh guru. Dimana dengan kesulitan-kesulitan yang dialami tersebut mempengaruhi hasil belajar siswa. Padahal matematika sendiri merupakan bagian dari ilmu pendidikan yang sering dijumpai dalam kehidupan sehari-hari. Tanpa disadari aktivitas yang dilakukan oleh manusia sehari-hari kerap menggunakan konsep matematika. Menurut Hasratuddin (2014) matematika adalah suatu cara untuk menemukan jawaban dari permasalahan yang dihadapi oleh manusia, cara menggunakan sebuah informasi, menerapkan pengetahuan mengenai suatu bentuk, ukuran dan menghitung, serta pola pikir manusia dalam menggunakan keterkaitan antara hubunganhubungan.

Kesulitan-kesulitan yang dialami oleh siswa biasanya dikarenakan siswa kurang memahami konsep, sulit untuk menerapkan rumus pada soal atau sulit untuk memecahkan suatu permasalahan. Salah satu materi yang dirasa sulit adalah materi transformasi geometri. Berdasarkan penelitian yang dilakukan oleh Maulani dan Zanthy (2020) menunjukkan bahwa kesalahan yang dilakukan siswa dalam menyelesaikan permasalahan pada materi transformasi geometri disebabkan oleh beberapa hal, diantaranya adalah cara belajar siswa yang tidak kontinu, siswa kurang berusaha dalam menyelesaikan permasalahan yang diberikan, siswa kurang menguasai konsep materi transformasi geometri, siswa kurang teliti dalam menyelesaikan permasalahan, dan siswa tergesa-gesa dalam menyelesaikan permasalahan yang diberikan. Akibat dari kesalahan yang dilakukan siswa tersebut menyebabkan hasil belajarnya kurang baik. Kesulitan-kesulitan yang dialami siswa tersebut dapat diatasi dengan cara guru menerapkan strategi atau pendekatan atau model ataupun metode pembelajaran yang sesuai dengan materi dan karakteristik siswa. Salah satu pendekatan yang dapat digunakan adalah pendekatan Relistic Mathematics Education (RME).

Menurut Tarigan (dalam Bunga dkk., 2016) pembelajaran matematika realistik atau Relistic Mathematics Education (RME) merupakan pendekatan yang ditujukan untuk pengembangan pola pikir praktis, logis, kritis, dan jujur dengan berorientasi pada penalaran matematika dalam menyelesaikan masalah. Dalam pembelajarannya, pendekatan RME menuntut siswa untuk m embangun pengetahuannya sendiri sehingga pembelajaran terasa lebih bermakna. Sedangkan menurut Ilma (dalam Fahrudhin dkk.,2018) RME merupakan pendekatan pembelajaran matematika yang bertitik tolak dari hal nyata bagi siswa, matematika disini dihubungkan dengan kenyataan dan dekat dengan kehidupan siswa. Menurut Gravemeijer RME memiliki tiga prinsip yaitu: (1) Penemuan kembali secara terbimbing melalui matematisasi progresif (Guided Reinvention Through Progressive Mathematizing); (2) Fenomena didaktik (Didactical Phenomenology); dan (3) Pengembangan model mandiri (self-developed models). Terdapat 5 tahap dalam pendekatan pembelajaran matematika realistik, yaitu: (1) Memahami masalah kontekstual; (2) Menjelaskan masalah kontekstual; (3) Menyelesaikan masalah kontekstual; (4) Membandingkan dan mendiskusikan jawaban; dan (5) Menyimpulkan. Pada tahap pertama, guru memberikan masalah kontekstual dan siswa memahami permasalahan tersebut. Pada tahap kedua, guru menjelaskan situasi dan kondisi soal dengan memberikan petunjuk atau saran seperlunya pada bagian yang belum dipahami siswa. Pada tahap ketiga, siswa secara individu menyelesaikan permasalahan kontekstual dengan cara mereka sendiri dan guru memotivasi siswa untuk menyelesaikan permasalahan. Pada tahap keempat, guru menyediakan waktu dan kesempatan pada siswa untuk membandingkan dan mendiskusikan jawaban dari soal secara berkelompok untuk didiskusikan di depan kelas. Pada tahap akhir, guru mengarahkan siswa untuk menarik kesimpulan (Hobri dalam Ningsih, 2014). 
Dalam pembelajaran yang menggunakan pendekatan RME dapat diterapkan penggunaan LKS berbasis etnomatematika. LKS berbasis etnomatematika ini diharapkan dapat menjembatani antara pengetahuan yang dimiliki siswa dengan pembelajaran realistik. Prastowo (dalam Haryonik dan Bhakti, 2018) menyatakan bahwa LKS ialah bahan ajar cetak yang berupa lembaran kertas berisi materi, ringkasan dan petunjuk atau arahan dalam pengerjaan tugas agar siswa memahami materi yang diberikan dengan harapan siswa dapat belajar mandiri. Sedangkan etnomatematika diartikan sebagai suatu bidang ilmu yang mempelajari hubungan antara matematika dan budaya. Etnomatematika juga dapat diartikan sebagai matematika yang digunakan dalam kelompokkelompok budaya yang dapat diidentifikasi (Ubiratan, 1985). Oleh karena itu peneliti ingin meneliti terkait penerapan LKS berbasis etnomatematika untuk meningkatkan hasil belajar siswa pada pokok bahasan transformasi geometri. Dimana hasil penelitian ini dapat dijadikan latar belakang untuk mengembangkan perangkat pembelajaran.

\section{Metode Penelitian}

Penelitian ini merupakan penelitian tindakan kelas (PTK) yang terdiri dari 2 siklus. Dimana sesuai dengan hakikat penelitian tindakan kelas, siklus kedua adalah perbaikan dari siklus pertama. Penelitian tindakan kelas (PTK) sendiri merupakan penelitian yang berkonteks kelas yang dilaksanakan untuk memperbaiki hasil pembelajaran, memperbaiki mutu pembelajaran, memecahkan masalah pembelajaran yang dihadapi oleh guru, atau mencoba hal baru untuk meningkatkan mutu dan hasil pembelajaran (Widayati, 2008). Tujuan dari penelitian ini adalah untuk meningkatkan hasil belajar siswa dengan menerapkan LKS berbasis etnomatematika pada materi transformasi geometri, khususnya pada subbab translasi dan refleksi. Subjek dalam penelitian ini adalah siswa dengan kemampuan matematika tinggi di SMK Negeri 1 Pujer, Bondowoso. Metode pengumpulan data yang digunakan adalah observasi dan tes. Observasi digunakan untuk mengamati aktivitas guru dan aktivitas siswa. Tes yang digunakan berupa soal uraian. Teknik analisis data yang digunakan adalah deskriptif kualitatif dan kuantitatif. Deskriptif kualitatif digunakan untuk menganalisis data observasi berupa aktivitas guru dan aktivitas siswa. Sedangkan deskriptif kuantitatif digunakan untuk menganalisis hasil tes individu.

Pada siklus pertama diterapkan pembelajaran secara konvensional, sedangkan pada siklus kedua diterapkan pembelajaran dengan menggunakan pendekatan RME dan LKS berbasis etnomatematika. Langkah yang diterapkan dalam pembelajaran RME pada siklus dua yaitu: memahami masalah kontekstual, menjelaskan masalah kontekstual, menyelesaikan masalah kontekstual, membandingkan dan mendiskusikan jawaban dan langkah yang terakhir adalah menyimpulkan. Di akhir pembelajaran tiap siklus dilakukan tes individu. Kemudian data hasil tes pada siklus satu dibandingkan dengan data hasil tes pada siklus dua, untuk melihat peningkatan hasil belajar siswa.

\section{Hasil dan Pembahasan}

Kegiatan pembelajaran pada siklus pertama dilaksanakan dengan baik, dimana siswa tertarik untuk mengikuti pembelajaran pada materi transformasi geometri subbab translasi dan refleksi. Dalam pembelajaran pada siklus ini guru memulai pembelajaran dengan mengucapkan salam dan memberi apresiasi kepada siswa. Kemudian guru menyampaikan tujuan dari pembelajaran yang akan dilakukan. Setelah itu guru mulai menyampaikan materi kepada siswa. Dalam penyampaian materi 
translasi dan refleksi, guru mengaitkan materi dengan pengetahuan relevan yang dimiliki siswa. Guru juga berusaha menyampaikan materi dengan bahasa yang baik dan komunikatif agar dimengerti oleh siswa dan siswa juga lebih aktif. Dalam kegiatan pembelajaran siswa juga diberi kesempatan untuk menanyakan hal yang kurang dimengerti. Di akhir pembelajaran guru memberikan tes individu kepada siswa berupa soal uraian. Setelah selesai tes, guru menutup kegiatan pembelajaran dengan memberi salam. Berdasarkan hasil tes siswa pada siklus pertama diperoleh data bahwa masih terdapat beberapa siswa yang mengalami kesulitan dalam menyelesaikan soal. Rata-rata siswa merasa sulit untuk menyelesaikan soal refleksi dikarenakan lupa rumus. Namun sebenarnya siswa paham akan konsep translasi dan refleksi. Berikut disajikan tabel skor tes yang diperoleh siswa pada siklus pertama.

Tabel 1. Skor Tes Siswa Pada Siklus Pertama

\begin{tabular}{|c|c|c|}
\hline No & Nama & Skor Tes \\
\hline 1 & Subjek 1 & 60 \\
\hline 2 & Subjek 2 & 50 \\
\hline 3 & Subjek 3 & 70 \\
\hline 4 & Subjek 4 & 45 \\
\hline 5 & Subjek 5 & 60 \\
\hline 6 & Subjek 6 & 55 \\
\hline 7 & Subjek 7 & 60 \\
\hline 8 & Subjek 8 & 55 \\
\hline 9 & Subjek 9 & 20 \\
\hline 10 & Subjek 10 & 20 \\
\hline 11 & Subjek 11 & 45 \\
\hline 12 & Subjek 12 & 60 \\
\hline
\end{tabular}

Dari hasil tes yang disajikan pada tabel 1, dapat diketahui bahwa hanya satu siswa saja yang memperoleh skor diatas 60. Sedangkan 11 siswa lainnya mendapatkan skor dibawah 60. Hal ini menunjukkan bahwa pembelajaran pada siklus pertama dirasa kurang berhasil. Berdasarkan data hasil observasi, guru dirasa kurang mampu untuk mengelola kelas karena masih terdapat beberapa siswa yang kurang kondusif dalam mengikuti kegiatan pembelajaran. Oleh karena itu dilakukan pembelajaran siklus kedua untuk memperbaiki kesalahan pada siklus pertama, dimana pada siklus kedua diharapkan siswa dapat lebih mudah memahami dan mengingat rumus translasi dan refleksi serta pembelajaran berjalan dengan kondusif. Pada siklus kedua diterapkan pendekatan RME dan menggunakan LKS berbasis etnomatematika.

Langkah pembelajaran RME yang lakukan adalah guru memulai pembelajaran dengan mengucapkan salam dan meminta siswa untuk berdoa. Kemudian guru menstimulasi siswa dengan menjelaskan transformasi geometri (translasi dan refleksi) menggunakan matriks dan memberikan LKS. Setelah itu guru meminta siswa untuk membentuk kelompok yang terdiri dari 3-4 orang. Langkah selanjutnya guru memberikan masalah kontekstual yang terdapat pada LKS. Guru juga menjelaskan perrmasalahan dan bagian yang belum dipahami oleh siswa. Pada tahap ini siswa mengumpulkan informasi yang relevan terkait translasi dan refleksi menggunakan matriks. Kemudian langkah selanjutnya siswa mencoba untuk menyelesaikan permasalahan yang telah diberikan dan guru memotivasi siswa untuk menyelesaikan permasalahan tersebut. Dalam menyelesaikan permasalahan tersebut guru memberikan kesempatan pada siswa untuk membandingkan dan mendiskusikan jawaban dengan temannya. Setelah selesai menyelesaikan permasalahan, guru mengarahkan siswa untuk menarik kesimpulan. Kemudian sebagai penutup 
dalam kegiatan pembelajaran, guru melakukan refleksi dan memberikan penguatan kepada siswa atas hasil kegiatan pembelajaran. Di akhir pembelajaran siklus kedua ini, guru juga memerikan tes individu yang berupa soal uraian. Setelah tes selesai, guru menutup kegiatan pembelajaran dengan memberi salam dan berdoa.

Berdasarkan hasil observasi aktivitas siswa pada pembelajaran siklus kedua ini, siswa lebih aktif dan bersemangat dalam mengikuti pembelajaran. Siswa juga lebih tertarik dan fokus dalam mengikuti pembelajaran karena materi yang disajikan dikaitkan dengan kehidupan di sekitar siswa. Suasana di kelas juga menjadi lebih kondusif dibandingkan dengan siklus pertama karena siswa fokus untuk mengikuti pembelajaran. Dengan menggunakan LKS berbasis etnomatematika siswa juga merasa senang dan lebih paham dalam mempelajari transformasi geometri (translasi dan refleksi) menggunakan matriks. Sehingga siswa lebih mudah untuk menyelesaikan permasalahan yang diberikan. Berdasarkan hasil observasi aktivitas guru, pada siklus kedua ini guru lebih baik dalam mengelola kelas. Dengan menggunakan RME dan LKS berbasis etnomatematika, guru juga lebih interaktif dengan siswa dan menggunakan bahasa yang mudah dipahami oleh siswa. Sehingga suasana di kelas menjadi lebih menyenangkan dan kegiatan pembelajaran menjadi lebih nyaman.

Berdasarkan tes yang dilakukan diakhir pembelajaran, skor yang diperoleh siswa pada siklus kedua disajikan pada tabel berikut.

Tabel 2. Skor Tes Siswa Pada Siklus Kedua

\begin{tabular}{|c|c|c|}
\hline No & Nama & Skor Tes \\
\hline 1 & Subjek 1 & 98 \\
\hline 2 & Subjek 2 & 70 \\
\hline 3 & Subjek 3 & 98 \\
\hline 4 & Subjek 4 & 83 \\
\hline 5 & Subjek 5 & 100 \\
\hline 6 & Subjek 6 & 100 \\
\hline 7 & Subjek 7 & 75 \\
\hline 8 & Subjek 8 & 60 \\
\hline 9 & Subjek 9 & 60 \\
\hline 10 & Subjek 10 & 85 \\
\hline 11 & Subjek 11 & 73 \\
\hline 12 & Subjek 12 & 60 \\
\hline
\end{tabular}

Dari hasil tes yang disajikan pada tabel 2, dapat diketahui skor yang diperoleh siswa rata-rata di atas 60 sedangkan hasil tes siswa pada siklus pertama rata-rata memperoleh skor dibawah 60 . Hal ini menunjukkan bahwa hasil tes yang diperoleh pada siklus dua lebih baik daripada hasil tes pada siklus pertama. Artinya nilai yang diperoleh siswa meningkat. Hal tersebut dikarenakan pada siklus kedua ini guru menggunakan LKS berbasis etnomatematika dan menerapkan pendekatan RME. RME sendiri memiliki beberapa karakteristik diantaranya dalam proses pembelajaran siswa dan guru samasama terlibat aktif; pembelajaran diawali dengan masalah kontekstual yang dapat dibayangkan oleh siswa; menciptakan suasana pembelajaran yang menyenangkan; siswa dapat menyelesaikan permasalahan secara individu ataupun kelompok; guru juga bertindak sebagai fasilitator (Marpaung, dalam Ningsih, 2014). Berdasarkan karakteristik-karakteristik yang dimiliki RME ini membuat siswa lebih nyaman dan lebih paham dalam memahami suatu materi. Sehingga siswa dapat lebih maksimal dalam menunjukkan hasil belajarnya. 
Untuk menjembatani masalah kontekstual yang dapat dibayangkan oleh siswa, pada penelitian ini digunakan LKS berbasis etnomatematika. Etnomatematika yang terdapat pada LKS tersebut adalah batik daun singkong Bondowoso. Dengan menggunakan LKS berbasis etnomatematika ini diharapkan siswa lebih termotivasi untuk belajar dan mampu meningkatkan hasil belajarnya. Selain itu siswa dapat memperoleh pengetahuan terkait matematika yang terdapat pada kehidupan seharihari dan lingkungan sekitar. Hal ini sejalan dengan penelitian yang dilakukan oleh Disnawati dan Nahak (2019) yang menunjukkan bahwa LKS berbasis etnomatematika tenun timor pada materi pola bilangan dapat meningkatkan motivasi belajar siswa dikarenakan terdapat unsur budaya, dan LKS tersebut juga terbukti dapat meningkatkan hasil belajar siswa.

\section{Kesimpulan}

Berdasarkan hasil penelitian yang diperoleh maka dapat disimpulkan bahwa penerapan lembar kerja siswa berbasis etnomatematika dalam pembelajaran mampu meningkatkan hasil belajar siswa, karena siswa merasa lebih nyaman, senang dan mudah dalam memahami materi transformasi geometri. Hal tersebut dikarenakan matematika yang dipelajari dekat dengan kehidupan siswa dan bersifat realistik. Dari hasil tes pada siklus pertama, rata-rata siswa memperoleh skor di bawah 60 . Sedangkan pada siklus kedua, rata-rata siswa memperoleh skor di atas 60.

Berdasarkan hasil penelitian di atas, peneliti memberi saran bagi penelitian selanjutnya untuk menerapkan pembelajaran menggunakan pendekatan RME atau menggunakan LKS berbasis etnomatematika karena terbukti dapat meningkatkan hasil belajar siswa pada materi transformasi geometri. Selain itu guru juga perlu mencari materi apa saja yang dapat diterapkan dalam pembelajaran yang menggunakan pendekatan RME atau LKS berbasis etnomatematika.

\section{Daftar Pustaka}

Bunga, N., Isrok'atun, \& Julia. (2016). Pendekatan Realistic Mathematics Education untuk Meningkatkan Kemampuan Koneksi dan Komunikasi Matematis Siswa. Jurnal Pena Ilmiah, $1(1), 441-450$.

Disnawati, H., \& Nahak, S. (2019). Pengembangan Lembar Kerja Siswa Berbasis Etnomatematika Tenun Timor pada Materi Pola Bilangan. Jurnal Elemen, 5(1), 64-79. https://doi.org/10.29408/jel.v5i1.1022

Fahrudhin, A. G., Zuliana, E., \& Bintoro, H. S. (2018). Peningkatan Pemahaman Konsep Matematika Melalui Realistic Mathematic Education Berbantu Alat Peraga Bongpas. ANARGYA: Jurnal Ilmiah Pendidikan Matematika, 1(1), 14-20.

Haryonik, Y., \& Bhakti, Y. B. (2018). Pengembangan Bahan Ajar Lembar Kerja Siswa dengan Pendekatan Matematika Realistik. MaPan: Jurnal Matematika Dan Pembelajaran, 6(1), 40-55. https://doi.org/10.24252/mapan.2018v6n1a5

Hasratuddin. (2014). Pembelajaran Matematika Sekarang dan yang akan Datang Berbasis Karakter. Jurnal Didaktik Matematika, 1(2), 30-42. Retrieved from http://www.jurnal.unsyiah.ac.id/DM/article/view/2075

Maulani, F. I., \& Zanthy, L. S. (2020). Analisis Kesulitan Siswa dalam Menyelesaikan Soal Materi Transformasi Geometri. Jurnal Gammath, 5(1), 16-25.

Ningsih, S. (2014). Realistic Mathematics Education: Model Alternatif Pembelajaran Matematika Sekolah. JPM IAIN Antasari, 1(2), 73-94.

Ubiratan, D. (1985). Ethnomathematics and its Place in the History and Pedagogy of Mathematics. 


\section{Journal of Mathematics Education and Learning}

Priciliya

For the Learning of Mathematics, 5(1), 44-48.

Widayati, A. (2008). Penelitian Tindakan Kelas. Junral Pendidikan Akuntansi Indonesia, VI(1), 8793. 